\title{
Higher Education Service Quality for International Students: A Literature Review
}

\author{
Jun Luo, Sarana Photchanachan \\ School of Management, Shinawatra University, Bangkok, Thailand \\ Email: 54736446@qq.com
}

How to cite this paper: Luo, J., \& Photchanachan, S. (2022). Higher Education Service Quality for International Students: A Literature Review. American Journal of Industrial and Business Management, 12, 1-9. https://doi.org/10.4236/ajibm.2022.121001

Received: December 6, 2021

Accepted: January 10, 2022

Published: January 13, 2022

Copyright (อ 2022 by author(s) and Scientific Research Publishing Inc. This work is licensed under the Creative Commons Attribution International License (CC BY 4.0).

http://creativecommons.org/licenses/by/4.0/ (c) (i) Open Access

\begin{abstract}
The paper addresses higher education (HE) service quality in China with respect to higher public education institution using the HESQUAL model. It has identified literature sources of five dimensions in the HESQUAL model and presented the HESQUAL model with 48 attributes in five dimensions based on the foregoing research. The researcher concluded the paper by investigating that for decades China's research on service quality of international students and based on the analysis of literature review from the research on service quality of international students. The researcher has found that the theoretical research was more conducted in the higher education sector than empirical research, and there were gaps between service quality and the perceptions of international students.
\end{abstract}

\section{Keywords}

HESQUAL, International Students, Literature Review, Service Quality

\section{Introduction}

Higher Education (HE) service quality is getting more and more attention by researchers in China, but fewer Chinese researchers conduct the kind of service quality research in the Chinese atmosphere (Hong, 2018). (Mortari \& Ubbiali, 2021) put that, "there are some instruments to assess the service quality in higher education". The purpose of the paper is to assess the quality of service for Higher Public Education Institution using the HESQUAL model, developed by (Teeroovengadum et al., 2016). Service quality in the higher education sector is increasingly recognized as a research field, and this puts a greater emphasis on meeting the expectations and needs of its participating customers who are the students (Chen \& Chen, 2010). Most studies consider students as primary cus- 
tomers (e.g., Bhuian, 2016).

\section{HESQUAL Model in Higher Education Sector}

(Icli \& Anil, 2014) proposed a new scale, called HEDQUAL (Higher Education Quality), which has only been assessed in Master of Business Administration (MBA) programmes. As key dimensions, the scale focuses on academic quality, administrative service quality, library service quality, quality of providing career opportunities and supporting services (Icli \& Anil, 2014). In the quest for international ranking and accreditation in higher education, quality must remain at the centre of the future research agenda. Future studies should delve into the notion of quality in education from a multidimensional model that incorporates quality, access, investment and relevance (Blanco-Ramírez \& Berger, 2014). Higher educational institutions, like any other service establishment, should strive to achieve excellence in service quality (Yousapronpaiboon, 2014) (Table 1 is HESQUAL model and Table 2 is the five dimensions in HESQUAL model).

Table 1. HESQUAL model.

\begin{tabular}{|c|c|c|}
\hline Author (s) & Model & Factor (s)/Findings \\
\hline \multirow{5}{*}{ (Teeroovengadum et al., 2016) } & \multirow{5}{*}{ HESQUAL } & Administrative quality, \\
\hline & & Physical environment quality, \\
\hline & & Core educational quality, \\
\hline & & Support facilities quality, \\
\hline & & Transformative quality \\
\hline
\end{tabular}

Table 2. The literature sources of five dimensions in HESQUAL model.

\begin{tabular}{|c|c|c|}
\hline Dimensions identified & Literature source & Sample statements from interviews/focus groups \\
\hline Administrative quality & (Narang, 2012) & $\begin{array}{l}\text { "There should not be much bureaucracy"; } \\
\text { "Procedures should be clearly stated"; } \\
\text { "Administrative staffs should always be willing to help students out". }\end{array}$ \\
\hline $\begin{array}{l}\text { Physical } \\
\text { environment quality }\end{array}$ & $\begin{array}{l}\text { (Narang, 2012), } \\
\text { (Wong et al., 2012) }\end{array}$ & $\begin{array}{l}\text { "A nice sports complex is important"; } \\
\text { "Lecture rooms must be well equipped". }\end{array}$ \\
\hline $\begin{array}{l}\text { Core } \\
\text { educational quality }\end{array}$ & (Narang, 2012) & $\begin{array}{l}\text { "Knowledge of academics"; } \\
\text { "Ability of lecturers to transmit enthusiasm"; "Up-to-date in their field"; } \\
\text { "Encourage participation of students in their learning process"; } \\
\text { "A culture of sharing and collaboration"; } \\
\text { "Faculty members are willing to help"; } \\
\text { "Course designed based in requirements of the students". }\end{array}$ \\
\hline $\begin{array}{l}\text { Support } \\
\text { Facilities } \\
\text { Quality }\end{array}$ & $\begin{array}{c}\text { (Sultan \& } \\
\text { Wong, 2012) }\end{array}$ & $\begin{array}{l}\text { "Adequate cafeteria"; } \\
\text { "Opportunities for extracurricular activities"; } \\
\text { "Computer laboratories available"; } \\
\text { "Photocopy and printing services". }\end{array}$ \\
\hline $\begin{array}{l}\text { Transformative } \\
\text { quality }\end{array}$ & $\begin{array}{l}\text { (Lomas, 2007), } \\
\text { (Srikanthan \& } \\
\text { Dalrymple, 2007) }\end{array}$ & $\begin{array}{l}\text { "Learning how to deal with emotions"; } \\
\text { "Developing critical thinking"; } \\
\text { "Acquiring job-related skills and knowledge"; } \\
\text { "Conduct research". }\end{array}$ \\
\hline
\end{tabular}

Source: Adapted from (Teeroovengadum, 2016). 
Table 3. HESQUAL model with 48 attributes in five dimensions.

\begin{tabular}{ll}
\hline Factors & Service quality dimensions and attributes \\
\hline
\end{tabular}

Administrative quality:

- Attitude and behavior including attributes No. 1 - 4;

- Administrative processes including attributes No. 5 - 7.

Physical environmental quality:

- Support infrastructure attributes including No. 8 - 11;

- Learning setting attributes including No. 12 - 14;

- General infrastructure attributes including No. 15 - 17.

Core educational quality:

- Attitude and behavior attributes including No. 18 - 23;

- Curriculum attributes including No. 24 - 27;

- Pedagogy attributes including No. 28 - 31;

- Competence attributes including No. 32 - 34.
1. Willingness of administrative staff members to help students;

2. Ability of administrative staff members to solve students' problems;

3. Politeness of administrative staffs;

4. Behaviour of administrative staff members imparting confidence in students;

5. Well standardized administrative processes so that there is not much bureaucracy and useless difficulties;

6. Administrative procedures are clear and well structured so that service delivery times are minimum;

7. Transparency of official procedures and regulations.

8. Availability of adequate cafeteria infrastructure;

9. Availability of adequate library infrastructure;

10. Availability of adequate recreational infrastructure;

11. Availability of adequate sports infrastructure;

12. Having adequate lecture rooms;

13. Having quiet places to study within campus;

14. Availability of adequate teaching tools and equipment

(e.g. Projector, White boards);

15. Favourable ambient conditions (ventilation, noise, odour, etc.) prevailing within the campus;

16. Safety on campus;

17. Appearance of buildings and grounds.

18. Lecturers understanding students' needs;

19. Lectures giving personal attention to students;

20. Availability of lecturers to guide and advise students;

21. Prevalence of a culture of sharing and collaboration among lecturers;

22. Behaviour of lecturers instilling confidence in students;

23. Lecturers appearing to have students' best interest at heart;

24. Clearly defined course content and course objectives;

25. Usefulness of module content and design to cater for the personal needs of students;

26. Challenging academic standards of programs to ensure students' overall development;

27. Relevance of course content to the future/current job of students; 28. Use of multimedia in teaching (e.g. use of overhead projector, power-point presentations);

29. Active participation of students in their learning process; 30. Provision of regular feedback to students with respect to their academic performance;

31. Well designed examinations and continuous assignment to promote the enhancement of knowledge skills;

32. Theoretical knowledge, qualifications and practical knowledge of lecturers;

33. Communication skills of lecturers;

34. Lecturers are up-to-date in their area of expertise. 


\section{Continued}

Support facilities quality:

- Support facilities attributes including No. 35 - 40.

Transformative quality:

- Transformative attributes including No. $41-48$.
35. Reasonable pricing and quality of food and refreshments on campus; 36. Availability of adequate IT facilities;

37. Availability and adequacy of photocopy and printing facilities;

38. Availability of transport facilities;

39. Amount of opportunity for sports and recreational facilities;

40. Availability and adequacy of extracurricular activities including those through clubs and societies.

41. Enabling students to be emotionally stable;

42. Increase in self-confidence of students;

43. Development in students' critical thinking;

44. Increase in self-awareness of students;

45. Development of problem-solving skills with respect to their field of study;

46. Enabling students to transcend their prejudices;

47. Acquiring adequate knowledge and skills to perform future job;

48. Increase in knowledge, abilities and skills of students.

Table 4. Past researches for service quality in higher education.

\begin{tabular}{|c|c|c|}
\hline Author (s) and publication & Finding (s) & Research place \\
\hline (LeBlanc \& Nguyen, 1997) & $\begin{array}{l}\text { - Reputation, faculty, administrative personnel had a significant } \\
\text { relationship with perceived service quality; } \\
\text { - Curriculum, physical evidence, responsiveness and access to } \\
\text { facilities as additional factors influencing perceived service quality. }\end{array}$ & Canada \\
\hline (Joseph \& Joseph, 1997) & $\begin{array}{l}\text { - Program, academic reputation, and career opportunities had a } \\
\text { relationship with service quality; } \\
\text { - Physical aspects, location, and time didn't have a direct } \\
\text { relationship with service quality. }\end{array}$ & New Zealand \\
\hline (Gatfield et al., 1999) & $\begin{array}{l}\text { - Adopted assessment method had a significant relationship with } \\
\text { students' satisfaction; } \\
\text { - There was a significant difference on satisfaction with students' } \\
\text { work experience; } \\
\text { - Age and gender had no relationship with students' satisfaction. }\end{array}$ & Australia \\
\hline (Yildiz \& Kara, 2009) & - To develop a measurement for service quality in higher education. & Turkey \\
\hline $\begin{array}{c}\text { (Rojas-Méndez, } \\
\text { Vasquez-Parraga, } \\
\text { Kara \& Cerda-Urrutia, 2009) }\end{array}$ & $\begin{array}{l}\text { - Students' satisfaction and perceived service quality did not have } \\
\text { a direct relationship with loyalty. }\end{array}$ & Chile \\
\hline $\begin{array}{l}\text { (Ibrahim, Wang, } \\
\text { \& Hassan, 2013) }\end{array}$ & - $\quad$ There was a gap between perceived service quality and expectation. & $\begin{array}{l}\text { Glasgow, } \\
\text { Strathclyde, } \\
\text { Stirling, West } \\
\text { of Scotland }\end{array}$ \\
\hline (Jain et al., 2013) & $\begin{array}{l}\text { Developing a model including program quality: curriculum, } \\
\text { industry interaction, input quality, academic facilities; and quality } \\
\text { of life: non-academic processes, support facilities, campus and } \\
\text { interaction quality. }\end{array}$ & India \\
\hline
\end{tabular}


(Garba \& Sentosa, 2015)

(Teeroovengadum et al., 2016)

(Ingaldi, 2018)

(Lu \& Pitchayadejanant, 2017)

(Khalaf \& Khourshed, 2017)

(Saduov, Madiyarova, Jempeissova, Selezneva, Shtiller, \& Fursova, 2018)

(Sokoli, Koren, \& Gutierrez, 2018)

(Sokoli, Koren, \& Shala, 2019)

(Munshi, 2019)

(Osman \& Saputra, 2019)

(Asnawi \& Setyaningsih, 2020)

(Sameena, 2020)

(Lima-Vargas,

Obaya, Lima-Vargas,

Rosales-Soriano, 2021)

(Mortari \& Ubbiali, 2021)
- A strongly significant relationship between the reliability, assurance and empathy with satisfaction;

- An insignificant relationship between tangibility and

Malaysia responsiveness with satisfaction of students.

- Developing a five-dimension HESQUAL model with 48 attributes.

Mauritius

- Overview of main methods of service quality analysis.

Poland

- To identify accuracy information, fulfilling, tailed advice, willing assistance, recommendation for the university to friends, and recommendation for friends to study in Thailand.

Thailand

- Tangibles (Physical Environment) affect, course content essential, Academic staff efficiency the most important, Responsiveness and empathy, economic side and reputation.

Egypt

- Computer facilities, library facilities, academic courses and future job prospects had a significant relationship with perceived service quality.

- The importance of investing in IT facilities by universities in order to improve students' satisfaction.

- Curricula had a relationship with students' satisfaction;

- Academic and non-academic qualities had a relationship with satisfaction.

- Using HESQUAL model to measure and improve service quality in higher education.

Kazakhstan

U.S.A

Slovenia

India

- To develop a HESQUAL model based on SERVQUAL model.

- Institutional image had a strongly significant impact on students' satisfaction;

Bangladesh

- Program quality had a significant relationship with service quality.

- Factors influence the perceived quality of students during the learning process.

Indonesian

- Core and value-added service quality.

UAE

- The impact of students' perception of quality towards their institution (teachers and administrators) on their academic performance and gender differences.

- Service learning is an interesting model that would allow for this and would guide practices that support a democratic education informed by virtue and ethics.

\section{The Development of Attributes in HESQUAL Model}

The researcher presented HESQUAL model with 48 attributes in five dimensions based on the foregoing research as in Table 3.

\section{Past Researches Concerning HESQUAL Model}

Based on the foregoing cases of different countries using HESQUAL in analyzing the results between customers' expectations and perceptions, the researcher will 
produce a table containing the dimensions of service quality in higher education as in Table 4.

\section{Conclusion and Future Research}

For decades, China's research on service quality of international students has been based on the analysis of literature review, and the researcher has found that the theoretical research was more conducted in the higher education sector than empirical research. Also, there were gaps between service quality and the perceptions of international students.

A large number of empirical studies have shown that the evaluation of customer (student) satisfaction should be based on the characteristics of the organization and customers, and it is difficult to find a unified evaluation scale.

Compared with the quality of higher education services, relevant research on the quality of education services for international students at home and abroad is not sufficient. Whether there are considerable deficiencies in both theoretical and empirical research, China's international student service quality management research has paid too much attention to the research of theories but ignored the empirical research. The specific performances are as follows: 1) the lack of a united definition of international students education services; 2) the relevant research on the quality of international students' educational services is not sufficient, and the quality characteristics of the education services of international students in China are not clear; 3) due to the limitations of the extant relevant research on the small sample, with the lack of representativeness of students' source, the small scope of the investigation, and an insufficient test of validity; 4) the lack of research on student satisfaction and the lack of research on the cross-culture factors, the different learning objectives of international students, the perception of quality service, and the influence of satisfaction and loyalty; 5) there has been little research on the service quality concerning international students and evaluation systems in Guizhou province, China (Zhang, 2018; Zhang et al., 2007; Song, 2018; Yang, 2009; Yun \& Chen, 2019).

For future research concerning service quality for the perceptions of international students, the research should be paid more attention to the empirical research more than theory research, and the respondents should include higher education sectors both in the public and private (Ren et al., 2019).

\section{Acknowledgements}

Sincere appreciations are to the advisor, Dr. Sarana Photchanachan, for the helpful guidance for me to complete the paper.

\section{Conflicts of Interest}

The authors declare no conflicts of interest regarding the publication of this paper. 


\section{References}

Asnawi, N., \& Setyaningsih, N. D. (2020). Perceived Service Quality in Indonesian Islamic Higher Education Context: A Test of Islamic Higher Education Service Quality (iHESQUAL) Model. Journal of International Education in Business, 13, 107-130. https://doi.org/10.1108/JIEB-11-2019-0054

Bhuian, S. N. (2016). Sustainability of Western Branch Campuses in the Gulf Region: Students' Perspectives of Service Quality. International Journal of Educational Development, 49, 314-323. https://doi.org/10.1016/j.ijedudev.2016.05.001

Blanco-Ramírez, G., \& Berger, J. B. (2014). Rankings, Accreditation, and the International Quest for Quality: Organizing an Approach to Value in Higher Education. Quality Assurance in Education, 22, 88-104. https://doi.org/10.1108/QAE-07-2013-0031

Chen, C. F., \& Chen, F. S. (2010). Experience Quality, Perceived Value, Satisfaction and Behavioral Intentions for Heritage Tourists. Tourism Management, 31, 29-35. https://doi.org/10.1016/j.tourman.2009.02.008

Garba, M. M., \& Sentosa, I. I. (2015). Expectations and Perceptions of African Students on Service Quality of Higher Institutions in Malaysian Private Universities. In International Conference on Trends in Business and Economics (pp. 30-36).

Gatfield, T., Barker, M., \& Graham, P. (1999). Measuring Student Quality Variables and the Implications for Management Practices in Higher Education Institutions: An Australian and International Student Perspective. Journal of Higher Education Policy and Management, 21, 239-252. https://doi.org/10.1080/1360080990210210

Hong, C. Z. (2018). The Literature Reviews About Higher Education Service Quality in Overseas. Proceedings of 2017 2nd International Conference on Education, Management and Systems Engineering (EMSE 2017), 139-142.

http://doi.org/10.12783/dtssehs/emse2017/12757

Ibrahim, E. B., Wang, L. W., \& Hassan, A. (2013). Expectation and Perceptions of Overseas Students towards Service Quality of Higher Education Institutions in Scotland. International Business Research, 6, 10-19.

Icli, G. E., \& Anil, N. (2014). The HEDQUAL Scale: A New Measurement Scale of Service Quality for MBA Programs in Higher Education. South African Journal of Business Management, 45, 31-43.

Ingaldi, M. (2018). Overview of the Main Methods of Service Quality Analysis. Production Engineering Archives, 18, 54-59. https://doi.org/10.30657/pea.2018.18.10

Jain, R., Sahney, S., \& Sinha, G. (2013). Developing a Scale to Measure Students' Perception of Service Quality in the Indian Context. The TQM Journal, 25, 276-294. https://doi.org/10.1108/17542731311307456

Joseph, M., \& Joseph, B. (1997). Service Quality in Education: A Student Perspective. Quality Assurance in Education, 5, 15-21. https://doi.org/10.1108/09684889710156549

Khalaf, M. A., \& Khourshed, N. (2017). Performance-Based Service Quality Model in Postgraduate Education. International Journal of Quality \& Reliability Management, 34, 626-648. https://doi.org/10.1108/IJQRM-04-2015-0059

LeBlanc, G., \& Nguyen, N. (1997). Searching for Excellence in Business Education: An Exploratory Study of Customer Impressions of Service Quality. International Journal of Educational Management, 11, 72-79. https://doi.org/10.1108/09513549710163961

Lima-Vargas, A. E., Obaya, A., Lima-Vargas, S., \& Rosales-Soriano, M. R. (2021). Perception of Institutional Quality as a Determining Factor in Academic Performance in Higher Middle School Students. The Educational Review, 5, 17-26.

https://doi.org/10.26855/er.2021.02.001 
Lomas, L. (2007). Zen, Motorcycle Maintenance and Quality in Higher Education. Quality Assurance in Education, 15, 402-412. https://doi.org/10.1108/09684880710829974

Lu, F., \& Pitchayadejanant, K. (2017). Chinese Students' Perceived Service Quality towards Thai Higher Education Institutes. Journal of Educational Administration, 13, 201-216.

Mortari, L., \& Ubbiali, M. (2021). Service Learning: A Philosophy and Practice to Reframe Higher Education. Athens Journal of Education, 8, 115-138.

https://doi.org/10.30958/aje.8-2-1

Munshi, R. (2019). Higher Education Service Quality Model (HESQUAL) to Improve Service Quality of Higher Education Institutes. International Journal of Research in $\mathrm{Hu}$ manities, Arts and Literature, 7, 181-190.

Narang, R. (2012). How Do Management Students Perceive the Quality of Education in Public Institutions? Quality Assurance in Education, 20, 357-371. https://doi.org/10.1108/09684881211263993

Osman, A. R., \& Saputra, R. S. (2019). A Pragmatic Model of Student Satisfaction: A Viewpoint of Private Higher Education. Quality Assurance in Education, 27, 142-165. https://doi.org/10.1108/QAE-05-2017-0019

Ren, Z. J., Zhou, Y. C., Qu, W., \& Ji, L. (2019). Qualitative Research Investigating the Challenges of Study and Life of International Study in China. Advances in Education, 9, 260-226.

Rojas-Méndez, J. I., Vasquez-Parraga, A. Z., Kara, A., \& Cerda-Urrutia, A. (2009). Determinants of Student Loyalty in Higher Education: A Tested Relationship Approach in Latin America. Latin American Business Review, 10, 21-39. https://doi.org/10.1080/10978520903022089

Saduov, A., Madiyarova, E. S., Jempeissova, G., Selezneva, I. E., Shtiller, M. V., \& Fursova, T. T. (2018). International Students' Satisfaction with University Services: The Case of Postgraduate Students from Central Asia.

https://www.semanticscholar.org/paper/International-students'-satisfaction-with-servi ces\%3A-Saduov-Madiyarova/4f02e69611f5b4267b180455855c1f90d3b1b502

Sameena, T. K. (2020). Students' Perceptions on Core Service Quality in Higher Education Institutions in UAE. International Journal of Education, 8, 43-49.

https://doi.org/10.34293/education.v8i2.1877

Sokoli, D., Koren, A., \& Gutierrez, C. (2018). Student's Perception of Academic Quality: A Review of the Literature. In V. Dermol, M. Smrkolj, H. Faletič, \& A. Ježovnik (Eds.), Integrated Economy and Society: Diversity, Creativity, and Technology (pp. 825-831). ToKnowPress.

Sokoli, D., Koren, A., \& Shala, K. (2019). HESQUAL-Tool for Analysis of Higher Education Service Quality. In Thriving on Future Education, Industry, Business and Society; Proceedings of the MakeLearn and TIIM International Conference 2019 (pp. 621-627). ToKnowPress.

Song, T. T. (2018). Research on the Development Trend of International Students' Education in China since the 21st Century. Master's Thesis, Yunnan University.

Srikanthan, G., \& Dalrymple, J. F. (2007). A Conceptual Overview of a Holistic Model for Quality in Higher Education. International Journal of Educational Management, 21, 173-193. https://doi.org/10.1108/09513540710738647

Sultan, P., \& Wong, H. Y. (2012). Service Quality in a Higher Education Context: An Integrated Model. Asia Pacific Journal of Marketing and Logistics, 24, 755-784. https://doi.org/10.1108/13555851211278196

Teeroovengadum, V., Kamalanabhan, T., \& Seebaluck, A. K. (2016). Measuring Service Quality in Higher Education: Development of a Hierarchical Model (HESQUAL). Quality Assurance in Education, 24, 244-258. 
https://doi.org/10.1108/QAE-06-2014-0028

Wong, K., Tunku, U., \& Rahman, A. (2012). Constructing a Survey Questionnaire to Collect Data on Service Quality of Business Academics. European Journal of Social Sciences, 29, 209-221.

Yang, J. H. (2009). Research on Intercultural Adaption of International Students in China. Shanghai Academy of Social Sciences Press.

Yildiz, S. M., \& Kara, A. (2009). The PESPERF Scale: An Instrument for Measuring Service Quality in the School of Physical Education and Sports Sciences (PESS). Quality Assurance in Education, 17, 393-415. https://doi.org/10.1108/09684880910992359

Yousapronpaiboon, K., (2014). SERVQUAL: Measuring Higher Education Service Quality in Thailand. Procedia-Social and Behavioral Sciences, 116, 1088-1095.

https://doi.org/10.1016/j.sbspro.2014.01.350

Yun, J. H., \& Chen, L. (2019). Issues on the Quality of Education Services for Foreign Students in China in the Background of the "Belt and Road": A Case Study of Yunnan Agricultural University. Education and Teaching Forum, No. 3, 3 p.

Zhang, L. L. (2018). The Research on the Management of Universities' International Students in China. Unpublished Ph.D. Dissertation, Northeast Normal University. https://cdmd.cnki.com.cn/Article/CDMD-10200-1020617323.htm

Zhang, M. Y., \& Liu, K. N. (2007). Reflections on Strengthening the Teaching and Management of International Students in China. China Higher Education Research, 5, 68-69. 